\title{
Service Learning: An Auditing Project Study
}

\author{
Gregory Kenneth Laing ${ }^{1}$ \\ ${ }^{1}$ School of Business, Faculty of Arts \& Business, University of the Sunshine Coast, Queensland, Australia \\ Correspondence: Gregory Laing, School of Business, Faculty of Arts \& Business, University of the Sunshine \\ Coast, Maroochydore DC Qld 4558, Australia. Tel: 61-754-594-675. E-mail: glaing@usc.edu.au
}

\author{
Received: October 26, 2012 Accepted: November 19, 2012 Online Published: December 11, 2012 \\ doi:10.5539/ies.v6n1p174 URL: http://dx.doi.org/10.5539/ies.v6n1p174
}

\begin{abstract}
There is a growing demand in higher education for universities to introduce teaching methods that achieve the learning outcomes of vocational education. The need for vocational educational outcomes was met in this study involving a service learning activity designed to provide basic professional auditing competencies. The details of the design and implementation of the auditing project are explained. The methodology employed in this study is qualitative in nature. Analysis was based on a survey designed to elicit feedback regarding the experience gained from participating in the audit project. The analysis indicates that the students perceived the audit project to be beneficial to their learning and development of accounting, communication and teamwork skills. Due to the limited number of participants and the qualitative methodology the results are not geralizabable. However, the results do provide support for the use of service learning activities to provide experiential learning and an awareness of community service consistent with the existing literature.
\end{abstract}

Keywords: service learning, auditing, vocational education, experiential learning

\section{Introducation}

\subsection{Introduction}

Vocational education has a long history in the Higher Education Sector with universities having played a role in discipline areas such as medicine, law, engineering and education. This emphasis on vocational education in the higher educational sector has a long history throughout Europe and the United States of America ( Heijke \& Koeslag, 1999; Stasz, Kaganoff \& Eden, 1994). The approach to teaching in these disciplines has involved providing some form of practical work experience. The medical discipline has the requirement for a period of service through a process commonly referred to as an internship or residency (Owen, Mathews, Phillips, Ramsey, Corrigan, Bassett \& Wenzel, 2011). The legal profession had their own form of internship, the article clerk, however this was conducted external from the university. The Law discipline in more recent times has introduced an experiential approach utilizing moot court room settings to provide the atmosphere and activity of an actual court hearing (Sturm \& Guinier, 2007). Medicine continues to utilise the internship or residency requirement for students in teaching hospitals linked to specific universities. In the education discipline students are required to complete a practicum in the class room of actual schools as part of the syllabus. All of these variations to the theme of providing actual experience to enhance the vocational skills of graduates have been applauded and refined over time.

In Australia the Higher education sector has moved to incorporate internships and what is more generally referred to as work-integrated-learning into the curriculum to increase the vocational skills of the graduates from all discipline areas (Patrick, Peach, Pocknee, Webb, Fletcher \& Pretto, 2008). Consequently, Australian universities have developed a university wide approach that seeks to encompass all students under the more common term of work-integrated-learning (Lawson, Fallshaw, Papadopoulos, Taylor \& Zanko, 2011; Cord, Bowrye \& Clements, 2010; Leveson, 1999). The concept of work-integrated-learning comes in a number of categories from the situation where students attend a work place and monitor the work with some involvement but certainly no compensation or remuneration to the situation where a contract is issued for a student to actually work in a limited capacity with remuneration. The first approach has the student as an observer and arguably provides limited learning outcomes. The second approach borders on replicating the internship of the medical discipline although such internship s do not involve the same full time level of work experience.

These approaches have been shown to enhance the level of learning of students and develop the vocational skills (Rama, Ravenscroft, Wolcott \& Zlotkowski, 2000). However, the focus of these approaches tends to be one sided in so far as the outcome is simply aimed at providing an educational experience for the student. There may be a benefit to the university at least in so far as it is perceived to be providing the students with educational 
outcomes consistent with learning goals. However, from the university perspective there are other goals that are embedded in their strategic aims and objectives, in particular the provision of services to the local community and society in general. So far as the structure and the manner in which the work-integrated-learning and internships are incorporated in the curriculum they do not adequately address nor encompass the wider goals of service to the local community or society. Boyer and Hechinger (1981) argued that universities should not only teach and conduct research they should involve their students in service to the community. Consistent with this philosophy Reinharz (1997) suggested consideration should be given to the inclusion of a category in the ranking process of universities that would recognize the actual record of community service performed.

\subsection{Importance of the Study}

An approach which does address these extended goals of the university and provides the necessary vocational skills is known as service learning. Service learning has been described as a form of active learning (Rama, Ravenscroft, Wolcott \& Zlotkowski, 2000) that involves service to society (Boyer \& Hechinger, 1981). The pedagogical justification for the inclusion of service learning in the curriculum is based on Kolb's (1984) model of experiential learning. Kolb $(1984,38)$ defined learning as the "process whereby knowledge is created through the transformation of experience" and this is consistent with the experiential process of service learning.

Service learning may take the form of a formal part of the degree in which credit is awarded in much the same way as an internship (Knechel \& Snowball, 1987) or as a non-credit activity in which students participation is purely voluntary (Strupeck \& Whitten, 2004). The literature does contain some examples of service learning aimed at meeting the vocational skills within the discipline of accounting and its application as a means of providing a service to the community (Rose, Rose \& Norman, 2005; Strupeck \& Whitten, 2004). This study seeks to add to the literature by providing details on the implementation and running of a service learning approach that address both the advancement of vocational skills and service to the community.

\subsection{Importance of the Problem}

The problems facing universities is three fold. Firstly, they need to meet the needs of the students seeking an education that encapsulates vocational skills. Secondly, they need to employ an approach to education that meets their goal for community involvement. Thirdly, they need to address the problem of attrition. Service learning is relevant to the missions of universities because it links the provision of vocational education through learning activities that involve providing service to the community.

\subsection{Service Learning Literature}

Service learning as the name implies is concerned with providing a service in the first instance followed by the learning experience and this is a key distinguishing feature from the concepts of work-integrated-learning or an internship. The service component is intended to be for the benefit of the community in two ways firstly by directly providing the service to those organizations that are not-for-profit or directly to socio-economically marginalized members of society (Hocking \& Hocking, 2008), and secondly by instilling a sense of empathy for others (Strupeck \& Whitten, 2004 ). The method and philosophy behind service learning was described as a form of "experiential learning through which participants in community service meet community need while developing their abilities for critical thinking and group problem solving, ... and the skills they need for effective citizenship." (National and Community Service Roles for Higher Education: A Resource Guide, 1994, p.12).

Community service is encouraged and supported by firms such as Hewlett Packard, the Body Shop and General Electric (Tucker, McCarthy, Hoxmeier \& Lenk, 1998). Numerous studies have reported that participation in service learning activities has benefited students in several ways. Service learning has been shown to promote altruistic behavior (Boss, 1994), enrich a students' skill base (Berson, 1994), reinforce content and concepts learnt in the classroom (Boss, 1994), result in a stronger commitment to studies (Sax \& Astin, 1997) and provide a greater competitive advantage for students (Still \& Clayton, 2004).

Studies have also identified that service learning fosters social responsibility, acceptance of diversity and leadership skills (Brandell \& Hinck, 1997; Kendrick, 1996), influences moral, social and emotional development (Rhoads, 1997; Eyler \& Giles, 1999). Service learning has also been shown to be an effective tool in developing better critical thinking and problem solving skills (Eyler \& Giles, 1999). With such a wide range of benefits, it should be no surprise that over 150 universities in the USA were reported by Dorsey (2001) to be operating various forms of service learning projects. 
There is a growing body of research that addresses the application of service-learning in the accounting curriculum (Zamora, 2012; Rose, Rose \& Norman, 2005; Still \& Clayton, 2004; Tschopp, 2004). A general set of guidelines were provided by Rama, Ravenscroft, Wolcott and Zlotkowski (2000) that were aimed at the issues likely to be encountered especially in regards to the accounting discipline with links to a wider body of research (Shafer, Park \& Ketchand, 1999; Apostolou, 1999; Driscoll, Holland, Gelmon \& Kerrigan, 1996). Drawing from this literature the steps for establishing and implementing service learning may be summarized as addressing; the intended student outcomes, differences in student characteristics, the process and setting. Based on the benefits and approaches to service learning activities identified in the literature the following model, Figure 1, was developed for application to the service-learning activity reported in this study.

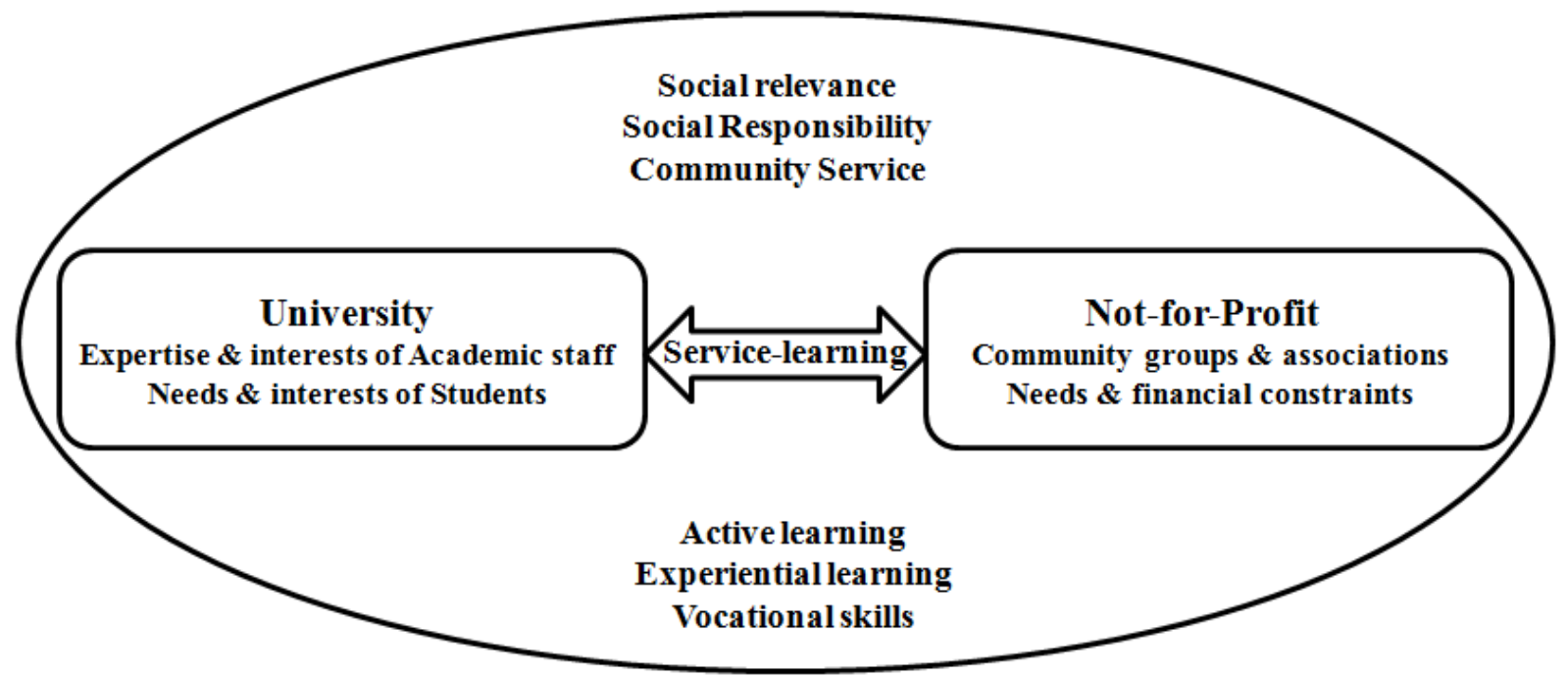

Figure 1. Service Learning Model

\subsection{Research Propositions}

In view of the qualitative methodology employed in this study the research is not intended to test hypothesis pertaining to the problem as identified. Rather the purpose is to explore the probity of the use of service learning to address the short comings of the internship and work-integrated-learning approaches adopted by universities. From this perspective two critical propositions emerge pertaining the use of service-learning to overcome the short comings of the internship and work-integrated-learning approaches.

The propositions emanating from the literature are expressed in the following terms:

1) That service learning facilitates the development of vocational skills - such as communication, team work, leadership, and relevant competencies.

2) That service learning reinforces classroom content - specifically by putting theory into practice.

3) That service learning promotes altruistic behavior - through community awareness and professional ethics.

4) That service learning develops a stronger commitment to studies - thereby resulting in higher retention of students and a reduction of attrition.

\section{Methodology}

The methodology employed in this study is a qualitative analysis (Patton, 2002) with support for the analysis coming from quantitative data derived from a survey of the students involved in the service learning project. This methodology is well established in the social sciences literature and is considered to be a valuable source for the provision of well-grounded, descriptions and explanations of potential knowledge pertaining to local contexts (Miles \& Huberman, 1984, 15). In terms of analyzing the data in respect of the propositions a form of triangulation is applied which draws upon the responses from the survey and the open ended questions to provide support for the overall inferences. Triangulation provides an important approach to addressing internal validation with in the qualitative data analysis methodology (Miles \& Huberman, 1984, 234).

In this study the service learning experience involved the pro-bono auditing of three not-for-profit associations registered under the Incorporated Association Act in Queensland Australia. This Act requires the incorporated association to have their financial records audited annually and to lodge a copy of the audited financial reports in 
order to renew the association's registration. Failure to lodge the audited financial reports within the prescribed deadline of the Act will incur a penalty and renewal may be rejected thus terminating the registration of the association. The service learning goals were develop using the basic competencies identified by Birkett (1993) as applicable to the auditing process. The provision of pro-bono accounting services promoted as a way in which the profession can contribute to the community and in particular not-for-profit organizations that in turn provide a community service (Shafer, Park \& Ketchand, 1999). This service learning activity was offered as a non-credit based activity conducted under the supervision of a CPA with the participants receiving a letter of acknowledgement of their participation together with a confirmation of the competencies emanating from the activity.

\subsection{Participants}

The sample in this study can be described as a purposeful and convenient sample comprising the students who volunteered to participate. Patton (2002) justified the use of a purposeful sample for qualitative research which is concerned with focusing on greater depth of understanding of a phenomenon in contrast to quantitative research which is aimed at generalizability. The sample consisted of nine second year level accounting majors enrolled in a Bachelor of Commerce accounting program. There were five females, four males and their ages ranged from 19 to 28. The goal was for the participants to learn auditing concepts and practices consistent with the basic competencies identified by Birkett (1993). The list of the auditing competencies is provided in Appendix A.

\subsection{Survey Procedures}

A survey was conducted through the internet using the web site "surveymonkey" this approach allowed for a professional survey design that could be easily accessed by students with the results being available immediately and with total anonymity for respondents. The survey questions are presented in Table 1 . The link to the survey was sent to all nine students that had been involved in the audit project with eight responding to the survey. This number of students is not large enough to be considered as representing anything more than feedback on the service learning activity embodied in the audit project. Accordingly no claims are made for generalizability of the results they are presented for the purpose of discussion relevant to this service learning activity.

\subsection{Study Design}

The service learning activity involved an auditing project which addressed the auditing needs of not-for-profit incorporated associations. The auditing project addressed a number of skills that are considered essential for professional accountants and subsequently will benefit students both as accountants and as members of society. As the CPA in charge, I was responsible for the supervision of the auditing activities and evaluation of the level of competencies displayed by each student. These skills are identified as follows:

Teamwork: The nature of the auditing activity is traditionally one the requires teamwork. Students learn allocate tasks, schedule completion times and work together to accomplish outcomes. For some students the activity provides the opportunity to gain leadership experience by taking responsibility and ownership of the assigned task.

Communication: The audit activity requires the provision of written reports, such as the notes to management detailing questions pertaining to issues identified, and the appropriate notes to accompany the financial reports. The activity also requires intra-team communication and reporting to the supervising CPA.

Experience with Audit Process: The student teams are taken through the preparation, risk assessment and testing stages of the audit activity.

Community Awareness: The students become more conversant with the value and diverse nature of the work of community groups and gain a greater awareness of their ability to make a positive contribution.

Professional Ethics: Students are made aware of the professional code of conduct expected from them in their dealing with the audit clients and within the team structure of the audit itself. Confidentiality of the information gained from an audit is especially reinforced by having an agreement signed by the student acknowledging the need to maintain confidentiality.

Students were advised of the audit project during normal accounting lectures and interviews were conducted to explain the commitment and the selection process. Due to the supervision requirements the number of students that could be accommodated was set at nine. Based upon their performance in the interview nine students were selected and invited to attend a briefing meeting before the audit project could proceed. The introductory briefing was conducted to explain the audit tasks that were to be undertaken and to present documentation that each student was required to read and acknowledge. Of particular importance was the need to maintain confidentiality of the information that would be revealed by the audit client. Then each student received a further set of notes and documents specifically addressing the audit requirements of incorporated associations. Students were then set the task of researching and completing a pre-audit check list to confirm that all the documentation had been 
provided by the client. Having completed the check list students were then asked to discuss their findings and to justify their conclusions - this encouraged participation and reflection on the accounting skills and knowledge that each would have to apply during the audit project. Students were then advised that teams would need to be formed to focus on separate areas of the audit and that these teams would in fact be required to provide and share information as the audit progressed. The students were reminded that this was to be a team effort and that each team have a team leader that would be appointed at a later date once the work had progressed sufficiently to allow for team dynamics to be observed. At all times the overall supervision was the responsibility of the CPA in charge.

There were three not-for-profit incorporated associations that were audited and there were nine students divided into three teams. The audit project was conducted in January 2011, for the financial year ending 31 December 2010, then again in January 2012 for the financial year ending 31 December 2011. Two of the incorporated associations used the accounting software MYOB and one used the accounting software QuickBooks, students were provided with basic instruction in the use of these software packages in their first year and minimal instruction was required for them to access the data from the relevant software.

The students were required to undertake the audit tasks on three days per week for the hours of $10.00 \mathrm{am}$ to $4.00 \mathrm{pm}$. The students showed a high level of dedication and commitment to the task and some flexibility was provided to allow for attendance by teams on different days. Teams were set deadlines for providing their progress reports back to the CPA supervisor for discussion and for dissemination with the other teams. This allowed teams to cross check the work and raised awareness of the skills being used not just in the audit activities but also in regards to the accounting knowledge that they had acquired in their studies to date - a form of reflection.

During the audit process each team had to prepare a list of questions and prepare a letter or note that would be given to management advising them of matters or issues which required explanation or consideration of changes to their policies or procedures. Each team prepared the wording and it was then checked and scrutinized for accuracy by the CPA supervisor before it was sent bearing his name to the management committee of the relevant incorporated association. Once an audit had been completed and the work checked by the CPA supervisor the financial report was prepared by the relevant team. For the incorporated associations the financial report is classified as a special purpose financial report which means that they are not bound by law to follow the promulgated accounting standards. The financial report contained the Statement of Financial Performance (Income Statement) the Statement of Financial Position (Balance Sheet) and the relevant notes attaching to and forming part of those statements together with the Auditors Report/Statement. At the end of each audit project (2011 and then 2012) a debrief was undertaken which encouraged reflection on the part of each student with regards to the skills that they had used or acquired and the extent to which they been able to apply their knowledge - in effect what had they learnt.

Having completed the audit project each student was provided with a letter confirm his or her participation in the audit project and confirmation of competencies achieved (refer Appendix A). It should be noted that not all students achieved a satisfactory level of performance in every competency listed in Appendix A. Each student was presented with his or her letter and the list of competencies achieved and where they had not achieved a satisfactory level for a particular competency an explanation was given so that they could learn from the experience and focus on making improvements.

\section{Results}

There were eight responses received all respondents answered questions 1 to 7 while only six responded to the open ended question which sought feedback and general comments regarding their experiences from the audit project. The responses to the survey are summarized in Table 1. 
Table 1. Survey Results

\begin{tabular}{|c|c|c|}
\hline 1. How helpful was the audit project to your learning about auditing? & $\begin{array}{r}\text { Extremely helpful } \\
\text { Very helpful }\end{array}$ & $\begin{array}{l}5(62.5 \%) \\
3(37.5 \%)\end{array}$ \\
\hline $\begin{array}{l}\text { 2. How useful was the audit project to you in learning to apply your } \\
\text { accounting skills? }\end{array}$ & $\begin{array}{r}\text { Extremely useful } \\
\text { Very useful }\end{array}$ & $\begin{array}{l}4(50.0 \%) \\
4(50.0 \%)\end{array}$ \\
\hline $\begin{array}{l}\text { 3. How well did the audit project help you to develop your } \\
\text { communication skills? }\end{array}$ & $\begin{array}{r}\text { Extremely well } \\
\text { Very well } \\
\text { Moderately well }\end{array}$ & $\begin{array}{l}1(12.5 \%) \\
6(75.0 \%) \\
1(12.5 \%) \\
\end{array}$ \\
\hline $\begin{array}{l}\text { 4. How effective was the audit project in helping you to develop your } \\
\text { teamwork skills? }\end{array}$ & $\begin{array}{r}\text { Extremely effe } \\
\text { Very effe } \\
\text { Moderately effe }\end{array}$ & $\begin{array}{l}2(25.0 \%) \\
5(62.5 \%) \\
1(12.5 \%) \\
\end{array}$ \\
\hline $\begin{array}{l}\text { 5. How well did the audit project do in meeting your expectations for } \\
\text { learning? }\end{array}$ & $\begin{array}{r}\text { Extremely well } \\
\text { Very well } \\
\end{array}$ & $\begin{array}{l}3(37.5 \%) \\
5(62.5 \%)\end{array}$ \\
\hline $\begin{array}{l}\text { 6. How important do you think voluntary service is to the } \\
\text { community? }\end{array}$ & $\begin{array}{r}\text { Extremely important } \\
\text { Very important }\end{array}$ & $\begin{array}{l}5(62.5 \%) \\
3(37.5 \%)\end{array}$ \\
\hline $\begin{array}{l}\text { 7. Overall, are you satisfied, dissatisfied, or neither satisfied nor } \\
\text { dissatisfied with your experience in the audit project? }\end{array}$ & $\begin{array}{l}\text { Extremely satisfied } \\
\text { Moderately satisfied }\end{array}$ & $\begin{array}{l}5(62.5 \%) \\
3(37.5 \%)\end{array}$ \\
\hline
\end{tabular}

The results are consistent with the findings of prior research that examined service learning activities in so far as the students reported a high level of benefits attributable to their participation in the audit project (Hesser, 1995). Whilst the small number in the sample limits the generalizability it also may be considered as supporting the literature that small group teaching provides students with a greater level of involvement and subsequent learning (Leveson, 1999). The responses to the three questions regarding the contribution of the service learning activity to the development of the skills pertaining to accounting, communication and teamwork may be characterized as being at the higher levels. The development of accounting skills features more prominently than the communication or the teamwork skills and this may be explained by the very nature of the audit tasks which are dependent on the application of knowledge directly pertaining to accounting.

The survey from the perspective of qualitative research is to provide confirmatory support for the propositions that have been developed. Accordingly, the analysis is limited to interpretation of the results relevant to the respective propositions. Proposition 1 is supported by the results from questions 1 to 5. Proposition 2 is supported by the results from questions 1, 2 and 5. Proposition 3 is supported by the results from question 6 . Proposition 4 is supported by the resullts from questions 5 and 7.

\subsection{Comments from Student Respondents}

Only six of the eight respondents provided comments and feedback to the open ended question. The attitudes of the students to the service learning activity is probably best expressed by the students own words. The comments were overwhelming positive in their appraisal of the audit project and confirm that the benefits of involvement in a service learning activity is consistent whether enacted as a non-credit activity. The following quotes maintain the anonymity of the students from the survey and are presented in the following number order:

Student 1

"It was a great experience, I just wish I had more exposure to it (time wise). It was great to put the theory we were taught into action and see how everything falls into place."

This is consistent with the literature that holds that service learning reinforces the learning from classroom content. This statement is also consistent with the survey results and proposition number 2 .

Student 2

"The experience on offer to students via the audit project is both singular and priceless. There is no other program that I am aware of wherein a student has this level of access to professionals and organisations on a voluntary basis. An opportunity where those willing to commit will see their efforts pay dividends in the form of confidence and experience."

This supports proposition number 2 and is consistent with the literature that holds that service learning reinforces the learning from classroom content.

Student 3

"I found that being part of the audit project helped me to understand the practical side of auditing and other accounting issues in business in 'real life'. It enabled me to apply the knowldege I have learnt from my degree. I enjoyed being part of a team. Working together to complete the task was helpful in gaining 
experience in a team environment. I am grateful for the opportunity to be a part of the audit project."

This is consistent with the literature that holds that service learning reinforces the learning from classroom content. This statement is also consistent with the survey results and provides support for the propositions 1 and 2 .

Student 4

"Good opportunity to receive some practical experience outside of the classroom."

This statement is also consistent with the survey results and is confirmatory of the proposition number 2.

Student 5

"Every accounting student should participate in the project. It is a fantastic opportunity for industry experience. ... I would love to have further involvement with the project, ...."

This is consistent with the literature and the survey results and supports proposition number 2.

Student 6

"The audit project allowed me to enhance my ability to work within a team. It also gave me invaluable practical experience in the task of conducting an audit. Overall, I would recommend it to any accounting student that they become involved in such projects."

This is confirmatory of the survey results and the proposition 1 and 2 .

The comments reveal that the students perceived that they had gained benefits from the service learning activity and this is reflected in their choice of words. The most prominent word used by the students in their responses is experience and this is with the literature that service learning is a form of experiential learning.

\section{Summary}

The feedback from the students indicates that they perceived very clear benefits arising from participating in the audit project. The comments reinforce the high level of the responses to the specific questions in regards to the service learning being helpful, useful and effective in providing the opportunity to develop their skills in accounting, communication and teamwork. These findings are consistent with the results reported in the literature (Zamora, 2012; Rose, Rose \& Norman, 2005; Still \& Clayton, 2004; Tschopp, 2004) and subsequently, provide support for the continued development and use of service learning activities to achieve desirable vocational learning outcomes.

This study provides evidence that even a non-credit activity will still attract students and is just as useful a means by which to provide the opportunity for students to engage in community service through the application of their knowledge and skills in a practical and real life setting. From the responses to the survey there is limited evidence that service learning can instil an awareness of the value of community service. Clearly, the results are not generalizable due to the small sample size and only offer the opportunity to make comparisons with prior research in order to draw inferences. This limitation was due to the overriding constraint for supervision of the students during the audit project as I was the only faculty member and CPA conducting the pro-bono auditing.

Future research may seek to examine the role of service learning in reducing attrition rates. Such research may provide stronger support for the application of service learning as an alternative method for addressing the problem of attrition and may be tested across a broader spectrum of disciplines.

\section{References}

Apostolou, B. (1999). Outcomes Assessment. Issues in Accounting Education, 14(1), 177-197. http://dx.doi.org/10.2308/iace.1999.14.1.177

Birkett, W. (1993). Competency Based Standards for Professional Accountants in Australia and New Zealand: Discussion Paper. the Institute of Chartered Accountants in Australia, Australian Society of CPA's, New Zealand Society of Accountants.

Boss, J. (1994). The effect of community service work on the moral development of college ethics students. Journal of Moral Education, 23(2), 183-198. http://dx.doi.org/10.1080/0305724940230206

Boyer, E., \& Hechinger, F. (1981). Higher Learning in the Nation's Service. Washington, DC: Carnegie Foundation for the Advancement of Teaching.

Brandell, M., \& Hinck, S. (1997). Service learning: Connecting citizenship with the classroom. NASSP Bulletin, 81(591), 49-56. http://dx.doi.org/10.1177/019263659708159109

Cord, B., Bowrye, G., \& Clements, M. (2010). Accounting Student's Reflections on a Regional Internship Program, Australasian Accounting. Business and Finance Journal, 4(3), 47-64. 
Dorsey, B. (2001). Linking Theories of Service-Learning and Undergraduate Geography Education. Journal of Geography, 100(3), 124-132. http://dx.doi.org/10.1080/00221340108978428

Driscoll, A., Holland, B., Gelmon, S., \& Kerrigan, S. (1996). An Assessment model for service-learning: Comprehensive case studies of impact on faculty, students, community, and institution. Michigan Journal of Community Service Learning, 3(1), 66-71.

Eyler, J., \& Giles, D. (1999). Where's the learning in service learning? San Francisco, CA: Jossey-Boss.

Heijke, H., \& Koeslag, M. (1999). The Labour-market Position of University Education and Higher Vocational Education in Economics and Business Administration: a comparison. Education Economics, 7(3), 259. http://dx.doi.org/10.1080/09645299900000022

Hesser, G. (1995). Faculty Assessment of Student Learning: Outcomes Attributed to Service-Learning and Evidence of Changes in Faculty Attitudes About Experiential Education. Michigan Journal of Community Service Learning, 2(1), 33-42.

Hocking, D., \& Hocking, R. (2009). An Answer to the AICPA core competencies challenge. Journal of Instructional Pedagogies, 1, 1-15.

Kendrick, J. (1996). Outcomes of service-learning in an Introductory Sociology course. Michigan Journal of Community Service learning, 3(1), 72-81

Kenworthy, A. (1996). Linking Business Education Campus Culture and Community: The Bentley Service-Learning Project. Journal of Business Ethics, 15(1), 121-131. http://dx.doi.org/10.1007/BF00380268

Kolb, D. (1984). Experiential Learning: Experience as the Source of Learning and Development. Englewood Cliffs, NJ: Prentice Hall.

Kolenko, T., Porter, G., Wheatley, W., \& Colby, M. (1996). A Critique of Service Learning Projects in Management Education: Pedagogical Foundations, Barriers, and Guidelines. Journal of Business Ethics, 15(1), 133-142. http://dx.doi.org/10.1007/BF00380269

Lamb, C., Swinth, R., Vinton, K., \& Lee, J. (1998). Integrating Service Learning into a Business School Curriculum. Journal of Management Education, 22(5), 637-654. http://dx.doi.org/10.1177/105256299802200506

Lawson, R., Fallshaw, E., Papadopoulos, T., Taylor, T., \& Zanko, M. (2011). Professional Learning in the business Curriculum: Engaging Industry, Academics and Students. Asian Social Science, 7(4), 61-68.

Leveson, L. (1999). Small Group Work in Accounting Education: an evaluation of a programme for first year students. Higher Education Research \& Development, 18(3), 361-377. http://dx.doi.org/10.1080/0729436990180306

Miles, M., \& Huberman, A. (1984). Qualitative Data Analysis: A Sourcebook of New Methods. Newbury Park: Sage Publications.

National and Community Service Roles for Higher Education: A Resource Guide. (1994). Washington, DC: The Corporation for National and Community Service.

Owen, C., Mathews, P., Phillips, C., Ramsey, W., Corrigan, G., Bassett, M., \& Wenzell, J. (2011). Intern culture, internal resistance: uptake of peer review in two Australian hospital internship programs. Australian Health Review, 35, 430-435. http://dx.doi.org/10.1071/AH10925

Patrick, C-j., Peach, D., Pocknee, C., Webb, F., Fletcher, M., \& Pretto, G. (2008). The WIL [Work Integrated Learning]report: A national scoping study [Australian Learning and Teaching Council (ALTC) Final report. Queensland University of Technology: Brisbane. Available online at: www.altc.edu.au and www.acen.edu.au (accessed 25 October 2012).

Patton, M. (2002). Qualitative Research \& Evaluation Methods, Thousand Oaks: Sage Publications.

Rama, D., Ravenscroft, S., Wolcott, S., \& Zlotkowski, E. (2000). Service-Learning Outcomes: Guidelines for Educators and Researchers. Issues in Accounting Education, 15(4), 657-692. http://dx.doi.org/10.2308/iace.2000.15.4.657

Reinharz, J. (1997). A better way of judging colleges. Boston Globe, December 27, A19.

Rhoads, R. (1997). Community service higher learning: Explorations of the caring self. Albany, NY: State University of New York Press.

Rose, J., Rose, A., \& Norman, C. (2005). A Service-Learning Course in Accounting Information Systems. Journal of Information Systems, 19(2), 145-172. http://dx.doi.org/10.2308/jis.2005.19.2.145 
Sax, L., \& Astin, A. (1997). The benefits of service: Evidence from undergraduates. Educational Record, 78, 25-32.

Shafer, W., Park, L., \& Ketchand, A. (1999). Giving Back: Pro bono accounting services. Journal of Accountancy, 188(5), 95-98.

Stasz, C., Kaganoff, T., \& Eden, R.A. (1994). Integrating academic and vocational education: a review of the literature, 1987-1992. Journal of Vocational Education Research, 19(2), 25-72.

Still, K., \& Clayton, P. (2004). Utilizing Service-Learning in Accounting Programs. Issues in Accounting Education, 19(4), 469-486. http://dx.doi.org/10.2308/iace.2004.19.4.469

Sturm, S., \& Guinier, L. (2007). The Law School Matrix: Reforming Legal Education in a Culture of Competition and Conformity. Vanderbilt Law Review, 60(2), 515-553.

Tschopp, D. (2004). The Seneca Babcock Business Plan: A Case Study in Using Service Learning to Meet the AICPA Core Competencies. Journal of Education for Business, 79(5), 261-266. http://dx.doi.org/10.3200/JOEB.79.5.261-266

Tucker, M., McCarthy, A., Hoxmeier, J., \& Lenk, M. (1998). Community Service Learning Increases Communication Skills Across the Business Curriculum. Business Communication Quarterly, 61(2), 88-99. http://dx.doi.org/10.1177/108056999806100211

Zamora, V. (2012). Using a Social Enterprise Service-Learning Strategy in an Introductory Management Accounting Course. Issues in Accounting Education, 27(1), 187-226. http://dx.doi.org/10.2308/iace-50102 


\section{Appendix A}

\section{List of Auditing Competencies}

\section{Element 1}

- A full understanding of the client's business environment is established, including systems, procedures and risks.

- The 'audit' risk associated with the client's business is identified

- Reasoning/conclusions about the client's business and risks are documented

- The review is completed prior to commencement of detailed audit work

\section{Competent Practitioners:}

Demonstrate a working understanding of processes and technologies utilised in organisational analysis, with particular reference to the determination of risk profiles

$\square$ Under supervision, review and document organisational structures and systems (in line with audit objectives), utilising relevant technologies (e.g. flow charting)

$\square$ Under supervision, develop risk matrices for the organization

$\square$ Upon request, contribute to assessments of the audit risks associated with the client's organization

$\square$ Under supervision, develop a preliminary discussion document on the nature of the proposed audit, focusing on audit objectives and client activities and risks

$\square$ Complete the above in agreed time frames

\section{Element 2}

- All the relevant professional standards and regulatory requirements applicable to the audit are identified

○ The over-riding or most important standards or regulations are determined

- How relevant standards/regulations will be drawn on in the audit process is determined

- The review of relevant standards and regulations is completed prior to commencement of detailed audit work

\section{Competent Practitioners:}

$\square$ Demonstrate an understanding of the professional and regulatory requirements (range and content) that generally impact organisations and audits.

$\square$ Subject to supervision, determine and document the full range of critical requirements applying to a particular organization.

$\square$ Determine and document the requirements relating to a particular audit, and demonstrate a working knowledge of those requirements.

$\square \quad$ Identify areas of ambiguity in requirements and areas where requirements do not appear to apply; refer these for expert or detailed consideration/interpretation.

$\square$ Under supervision, develop schedules of the regulatory requirements that are to apply to the proposed audit.

$\square$ Complete the above in agreed time frames.

\section{Element 3}

- Audit objectives are achieved, according to plan

- The audit process is undertaken and completed in a professional manner

- An appropriate documentary trail is established

- The audit is completed on time

\section{Competent Practitioners:}

$\square$ Demonstrate a thorough understanding of the mechanics of auditing in organisational settings.

$\square$ Work (with team) to implement the audit plan to defined timelines.

$\square$ Where necessary, flag problems with the plan and recommend changes.

$\square$ Document work done, and maintain audit working papers.

$\square$ Draft conclusion on audit in sphere of responsibility. 